\title{
Incidence of Clinical False Pregnancy among Breeds of Dogs at the Veterinary Teaching Hospital University of Agriculture Makurdi Benue State Nigeria
}

\author{
Wachida Ndumari ${ }^{1 *}$, Adi Deborah Se-ember ${ }^{2}$, Adesina Oluwatosin ${ }^{3}$ and Ijabo Hope Mhohe ${ }^{4}$ \\ Department of Veterinary Surgery and Theriogenology, University of Agriculture, Nigeria
}

Submission: January 12, 2019; Published: Febrauary 05, 2019

*Corresponding author: Wachida Ndumari, Department of Veterinary Surgery and Theriogenology, College of Veterinary Medicine, University of Agriculture P.M.B 2373, Makurdi, Benue State Nigeria.

\begin{abstract}
Summary
False pregnancy in bitches has serious economic impact on dog breeders. This study was therefore, designed to look at the incidence in bitches presented at the Veterinary Teaching Hospital, University of Agriculture Makurdi Benue State Nigeria from the year $2012-2017$ (5 years) and proofer solution to the problem; data of clinical cases from Hospital record was collected and analyzed based on breed, age, parity and diagnostic method, total number of 15 clinical cases were used in this work. Results show that the incidence of false pregnancy was higher in Russian shepherd 7(46.66 \%) followed by Alsatian 5(33.33\%) but lower in Mastiffs 2(8 \%) and Rottweiler 1(4 \%). Bitches at age 2 years recorded the highest incidence $7(46.66 \%)$, followed by a year of age $6(40 \%)$ and lastly those at 4 years $2(13.33 \%)$, there was no incidence recorded in those that are at age 3 years $0(0 \%)$. Based on parity, false pregnancy was higher in bitches in the first parity $13(86.66 \%)$ followed by those in third $2(13.33 \%)$ and absent in those in second parity $0(0 \%) .9(60 \%)$ of the cases were diagnosed by visual observation while $6(40 \%)$ by the used of ultrasonography, no treatment was instituted to manage the confirmed cases. In conclusion, false pregnancy in bitches is influence by breed age and parity.
\end{abstract}

Keywords: Age; Bitch; Breed; False pregnancy; Parity; Incidence

\section{Introduction}

False pregnancy is a clinical phenomenon in which a nonpregnant female exhibits maternal behavior and shows physical signs of pregnancy at the end of dioestrus [1]. The terms false and pseudopregnancy are often used interchangeably but they don't always refer to the same hormonal situation. The term pseudopregnancy refers specifically to the non-pregnant luteal phase, usually in reference to an animal that is induced to ovulate by coitus, when serum concentration of progesterone is high [1]. Progesterone causes mammary gland development and weight gain but not the other behavior and false changes of pregnancy [1]. In contrast to pseudopregnancy, false pregnancy is thought to be caused by the declining serum progesterone concentration associated with the end of luteal phase, which in turn causes an increase in serum prolactin concentration. Prolactin causes lactation and maternal behavior observed in false pregnancy $[1,2]$. False pregnancy is a common phenomenon in bitches because the bitch is known to ovulate spontaneously and have a long luteal phase [2].

False pregnancy is considered as a normal phenomenon in bitches. It is not associated with any reproductive abnormalities $[1,2]$. The occurrence of the false pregnancy provides evidence that ovulation took place during the preceding cycle and that the hypothalamic- pituitary- gonadal axis is intact $[1,3]$. The reasons why some bitches are more prone to developing clinical signs and why the severity of the clinical signs varies from cycle to cycle are not known. False pregnancy occurs frequently in bitches because the metoestrus, proestrus phase of the cycle is approximately the same duration as pregnancy and is characterized by clinical signs such as nesting, weight gain, mammary enlargement and lactation [1]. It occurs in nonpregnant bitch at about 6-12 weeks after oestrus and these changes result in typical mammary activity, or is presented as a clinical problem involving changes like those seen in late pregnancy or the early post-partum period [4-6]. The exact incidence of clinical false pregnancy or its distribution among breed is not known, although it has been estimated to be as high as $50-75 \%[6]$.

The pituitary hormone prolactin plays a central role in the patho-physiology of overt false pregnancy, but its exact role is not completely understood [1]. The incidence of clinical false pregnancy may be influenced by age, breed, parity and environmental factors. Nutrition may also have an influence on the occurrence of false pregnancy [7]. The purpose of this study 
therefore, is to investigate on whether the incidence of clinical cases of false pregnancy is influenced by age, breed and parity.

\section{Materials and Methods}

The study was conducted at the Veterinary Teaching Hospital, University of Agriculture Makurdi Benue State Nigeria. Makurdi lies approximately on Latitude $70.44^{\prime} \mathrm{N}$ and Longitude 80.54' E, in the Southern Guinea Savannah zone of Nigeria with a temperature range of $22.5{ }^{\circ} \mathrm{C}$ to $40{ }^{\circ} \mathrm{C}$ and annual rain fall of 1,290 $\mathrm{mm}$ [8]. Data were collected from case files that had documented information on clinical cases of false pregnancy in bitches at the Veterinary Teaching Hospital from 2012-2017 (5 years). Data was analyzed with regards to breed, age, parity and diagnostic method. Percentage distribution was employed to analyze the data collected and the results presented in form of table.

\section{Results}

Table 1: Incidence of False Pregnancy base on Breed.

\begin{tabular}{|c|c|c|c|c|}
\hline Breed & Alsatian & $\begin{array}{c}\text { Russian } \\
\text { Shepherd }\end{array}$ & Rottweiler & Mastiff \\
\hline $\begin{array}{c}\text { Incidence of false } \\
\text { pregnancy (n=15 }\end{array}$ & 5 & 7 & 1 & 2 \\
\hline Percentage (\%) & 33.33 & 46.66 & 4 & 8 \\
\hline
\end{tabular}

Table 2: Incidence of false pregnancy based on age.

\begin{tabular}{|c|c|c|c|c|}
\hline Age (Year) & 1 Year & 2 Years & 4 Years & 4 Years \\
\hline $\begin{array}{c}\text { Incidence of false } \\
\text { pregnancy }(\mathrm{n}=15)\end{array}$ & 6 & 7 & 0 & 2 \\
\hline Percentage (\%) & 40 & 46.66 & 0 & 13.33 \\
\hline
\end{tabular}

Table 3: Incidence of false pregnancy base on parity.

\begin{tabular}{|c|c|c|c|}
\hline Parity & First & Second & Third \\
\hline Incidence of false pregnancy (n=15) & 13 & 0 & 2 \\
\hline Percentage (\%) & 86.66 & 0 & 13.33 \\
\hline
\end{tabular}

Table 4: Methods used to diagnosed the incidence of false pregnancy.

\begin{tabular}{|c|c|c|}
\hline $\begin{array}{c}\text { Means of } \\
\text { Diagnosis }\end{array}$ & Ultrasonography & $\begin{array}{c}\text { Visual Observation of } \\
\text { Disappearance of Sign }\end{array}$ \\
\hline $\begin{array}{c}\text { Number of bitches } \\
(\mathrm{n}=15)\end{array}$ & 6 & 9 \\
\hline Percentage (\%) & 40 & 60 \\
\hline
\end{tabular}

The breeds of dogs available for these studies were Alsatian, Russian shepherd, Rottweiler and mastiffs. Out of 15 clinical cases of false pregnancy in bitches recorded during the period of study $5(33.33 \%)$ were recorded in Alsatian, 2(8\%) in Mastiffs 1(4\%) in Rottweiler and 7(46.66 \%) Russian Shepherd (Table 1). Age distribution of false pregnancy Table 2 showed that more cases were observed in the bitches that were at 2 years $7(46.66 \%)$, followed by those that were at a 1year old 6(40\%) and lastly those at 4 years $2(13.33 \%)$, there was no incidence recorded in those that are at 3 years of age $0(0 \%)$. Prevalence according to parity Table 3 indicates that $13(86.66 \%)$ was observed in bitches in first parity, $2(13.33 \%)$ in third parity and none was observed in those in second parity $0(0 \%)$. The diagnostic methods employed to confirm these cases were ultrasonography
$6(40 \%)$ and visual observation of disappearance of pregnancy signs $9(60 \%)$ (Table 4). None of the 15 clinical cases presented to Hospital was managed with any drug because the signs has disappeared before the cases were brought to the Hospital.

\section{Discussion}

The findings of this study show that the incidence of false pregnancy or its distribution across breeds is higher in Russian shepherd 7(46.66\%), followed by Alsatian 5(33.33\%), then Mastiff 2(8\%) and lastly Rottweiler 1(4\%); this is at par with the estimation of 50-75\% in bitches by [6]. Based on age in years, bitches that were 2 years of age recorded the highest incidence of false pregnancy $7(46.66 \%)$, followed by those that were at a 1 year old 6(40\%), then those that were at 4 years $2(13.33 \%)$, no incidence was recorded in those that were at 3 years old. The higher incidence of false pregnancy recorded in bitches between 1-2 years of aged could probably be due to early mating of these bitches in their first oestrus as they reach puberty (bitches attain puberty between $1 \frac{1}{2}-2$ years of age though it varies across breed, plane of nutrition and management practices).

The non-incidence observed in those at 3 years old could probably mean that it is the best age to mate bitches; at this age they are sexually matured, and must have experienced the first and second oestrus. The incidence of false pregnancy was higher in first parity 13 (86.66 \%) followed by third parity $2(13.33 \%)$ and absent in the second parity, the reason for that have already been explained that, most bitches in the first parity are between ages $1 \frac{1}{2}-2$ years, second parity 3 years and third parity 4 years of age respectively. The use of ultrasonography to confirm pregnancy in bitch is gaining acceptance by dog breeders in this part of the world. Most of the cases were presented as clinical cases for pregnancy confirmation and some after pregnancy signs have disappeared; some breeders did not see the need to confirm pregnancy using diagnostic ultrasound machine and this accounted for $6(40 \%)$ cases confirmed by ultrasound and $9(60 \%)$ visual observation. To reduce economic loss due to false pregnancy, dog breeders are advised as a routine reproductive management practice to scan their bitches between 21-22 days post mating to confirm the pregnancy status of their bitch so that early intervention will be instituted if there is a case of false pregnancy to avoid waiting for full gestational length, they should also not wait for the sign of pregnancy to disappear before seeking for intervention and they should mate their bitches from 2- 3 years of age because the incidence of false pregnancy at this age is minimal.

Management: Even though false pregnancy is self-limiting, mild cases need no treatment other than discouraging the maternal behaviour by placing an Elizabethan collar to prevent licking of the mammary glands as recommended by [2]. Nevertheless, it may be advisable to pharmacologically treat even in mild cases of false pregnancy in bitches with repeated episodes considering the possible relationship between false pregnancy and subsequent development of mammary tumors 
[9]. Sex steroid therapy such as Veterinary preparation of androgen including testosterone and synthetic androgen can supress lactation. Side effects can include clitoris hypertrophy, other form of virilisation, and epiphora [2]. Prolactinsuppression therapy involving the use of bromocriptine and carbergolin administered in high doses [10-12]. Cabergoline can be administered once a day. This crosses the blood brain barrier only slightly and consequently has a much less central emetic effect when compared to some other dopamine agonist. $[5,6,14,15]$ Ovariectomy: Predisposed bitches not intended for breeding should be spayed as this is the only permanent preventive measure $[6,16]$. This should be preferably carried out during anoestrus because if done during lactation can lead to an extended pseudopregnancy.

\section{Conclusion}

False pregnancy is prevalent in all breeds of dogs and it is affected by age parity and breeds. There is a need to tackle the reoccurrence/prevalence of false pregnancy in bitches; as this seems to have serious socio-economic impact on the lively hood of dog breeders.

\section{Acknowledgement}

Authors of this report are highly thankful to the Director Veterinary Teaching Hospital, Federal University of Agriculture Makurdi for given us access to the clinical case files.

\section{References}

1. Razzaque WAA, Kafil Husain, Sudarshan Kumar (2008) False pregnancy in bitch. Veterinary World 1(3): 92-95.

2. Gobelb C, Cocannon PW, Vestegen (2001) Canine pseudopregnancy: A Review. International Veterinary information service, USA.

3. Grunau B, Nolte I, Hoppen HO (1996) Investigation on the pseudopregnancy in the bitch with the prolactin inhibition metergoline and bromocryptine. Tierarztl prax 24(2): 149-155.

4. Allen WE (1986) Pseudopregnancy in the bitch: the current view on aetiology and treatment. Journal of small animal practice, 27(7): 419424.

5. Jochle W, Ballabio R, Disalle E (1987) Inhibition of lactation in the Beagle bitch with the prolactin inhibitor cabergoline (FCE 21336): Dose response and aspects of long-term safety. Theriogenology 27(5): 799810.

6. Johnston SD (1980) False pregnancy in the bitch. In: Marrow DA (Eds.) Current Veterinary Theriogenology. Philadelphia: WB Saunders CO, USA. pp. 623-624.

7. Lawler DF, Johnston SD, Keltner DG, Ballam JM, Kealy RD, et al. (1999): Animal Journal veterinary research. 60: 820-825.

8. Time EO, Tor $\mathrm{T}$ (2006) The changing Rainfall pattern and its implication for flood frequency in Makurdi Northern Nigeria Journal of Apply Science and Environmental Management 10(3): 97-102.

9. Verstegen J (1999) interet et application desantiprolactique en la cancerologie chezla chienne. In; proceedings of the $24^{\text {th }}$ world small Veterinary congress paris, France.

10. Mialot SP, Lagneau F, Chaffus S (1981) Inhibition de la lactation de la pseudopregnancy chez chienne parla bromocryptine. Rec Med Vet 157: $351-365$

11. Grunau B (1994) Zarbehandlung Von prolakitinbei pseudograviditat der Hundin. Inaugural Dissertation. Tierarz tliche Hochschule Hannover, Germany.

12. Arbeiter K, Brass W, Balhbio R (1988) Treatment of pseudopregnancy in bitch with cabergoline an ergoline deriotative Journal of small animals practice 29(12): 781-788.

13. Heavy MA, Cauvin A, Dale M (1997) Effect and Mechanism of the antiprolactin drug cabergoline on pseudopregnancy in the bitch. J small anim pract 38(8): 336-339.

14. Dumon C, Dumoulin PY, Collect JP (1993) Traitement de la lactation de pseudogestatation chez la chienne per la Cabergoline prat. Med Chir Anim Comp 21: 177-181.

15. Jochle W, Arbeiter K, Post K (1989) Effect of pseudopregnancy, pregnancy and interoestrous intervals of pharmacological suppression of prolactin secretion in female dogs and cats. J reprod fertil suppl 39: 199-207.

16. Allen WE (1986) The current view on ethology and treatment. Journal of small animal practics 27: 419-424.

\begin{tabular}{l} 
Your next submission with Juniper Publishers \\
will reach you the below assets \\
- Quality Editorial service \\
- Swift Peer Review \\
- Reprints availability \\
- E-prints Service \\
- Manuscript Podcast for convenient understanding \\
- Global attainment for your research \\
- Manuscript accessibility in different formats \\
( Pdf, E-pub, Full Text, Audio) \\
- Unceasing customer service \\
Track the below URL for one-step submission \\
https://juniperpublishers.com/online-submission.php \\
\hline
\end{tabular}

